\title{
Reflets
}

Revue ontaroise d'intervention sociale et communautaire

\section{À la mémoire de Brian Ouellette}

\section{Nérée St-Amand}

Volume 12, numéro 1, 2006

Spiritualité et intervention sociale

URI : https://id.erudit.org/iderudit/013436ar

DOI : https://doi.org/10.7202/013436ar

Aller au sommaire du numéro

Éditeur(s)

Reflets : Revue ontaroise d'intervention sociale et communautaire

ISSN

1203-4576 (imprimé)

1712-8498 (numérique)

Découvrir la revue

Citer ce document

St-Amand, N. (2006). À la mémoire de Brian Ouellette. Reflets, 12(1), 18-18.

https://doi.org/10.7202/013436ar

Tous droits réservés (C) Reflets : Revue ontaroise d'intervention sociale et communautaire, 2006

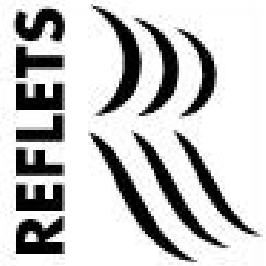

Ce document est protégé par la loi sur le droit d'auteur. L'utilisation des services d'Érudit (y compris la reproduction) est assujettie à sa politique d'utilisation que vous pouvez consulter en ligne.

https://apropos.erudit.org/fr/usagers/politique-dutilisation/ 


\section{À la mémoire de Brian Ouellette}

Au moment où nous étions à finaliser ce numéro de Reflets, nous apprenions la mort inattendue de Brian Ouellette, professeur à l'École de service social, Université St-Thomas, Fredericton Nouveau-Brunswick.

Brian a été l'un des principaux artisans au Canada de l'intégration de la spiritualité dans la formation et dans la pratique du service social. Il a beaucoup travaillé pour faire en sorte que la spiritualité soit à la fois comprise et vécue dans sa communauté et dans notre profession; qui plus est, il vivait cette spiritualité au quotidien et cela transpirait dans ses propos, ses écrits, ses rêves.

Il nous a beaucoup aidés avec ce numéro. En plus d'arbitrer deux des articles y apparaissant, il nous a proposé des auteurs qui s'intéressent à la dimension spirituelle de l'intervention sociale. Nous avions même prévu une entrevue avec lui pour cette section-ci.Au moment d'effectuer cette entrevue, nous apprenions son décès. Nous avons alors choisi de ne pas remplacer cette entrevue par une autre, soulignant de cette façon le grand vide que Brian laisse derrière lui.

Dans une profession qui cherche à asseoir ses assises sur des valeurs de transcendance, dans une profession qui fait la promotion du dépassement de soi, il servira de modèle. Le message qu'il laisse, tant dans sa vie personnelle que professionnelle, est celui d'une recherche constante d'absolu, de dépassement. À nous toutes et à nous tous, engagés dans le renouvellement des pratiques de l'intervention sociale, il laisse beaucoup de pistes à poursuivre pour une profession qui se cherche.

Nous lui dédions ce numéro en reconnaissance pour ce qu'il a fait pour la spiritualité en intervention sociale.

\section{Nérée St-Amand}

Responsable du numéro 